Oriental Journal of History, Politics and Law Vol.1 (1), pp.01-03, 23 May,

2021 Available online at http://supportscience.uz/index.php/ojhpl

(C) 2021 Support Science LLC

DOI: https://doi.org/10.37547/supsci-ojhpl-01-01

\title{
LINGUISTIC FEATURES OF LEGAL COMMUNICATION PHRASES IN ENGLISH AND UZBEK
}

\author{
Yasmina Karimova \\ Student Uzbekistan State University of World Languages Tashkent, Uzbekistan
}

\begin{abstract}
A expressions with legal semantics. The author gives expressions corresponding to the subject of the article and demonstrates the pragmatic implementation of their legal content. The theoretical part of the article is confirmed by the corresponding examples of English and Uzbek expressions with legal meaning.
\end{abstract}

EY WORDS: Phrase, legal content, jurisprudence, legal, social sphere, English society, Uzbek society.

\section{NTRODUCTION}

Only due to independence, Uzbek has become a state language, a language used in negotiations with other countries, the creation of laws, the language of scientific research. Because language is a social phenomenon, it develops and becomes richer in relation to the life of the people to whom it belongs. Therefore, any change in society is primarily reflected in language. One of the important tasks of linguistics is to regulate the changes that take place in the language, in general, to ensure that the development of language is on the right track.

The reform of the legal system in our country is based on the experience of developed democracies, as well as the rich heritage of our national statehood, which has a history of several thousand years. The study of the legal system of other countries, the creative use of their rich experience raises a very important issue for linguistics, such as the comparative study of the legal terms of Uzbek and foreign languages. In addition, after gaining independence, our country has entered into contractual and legal relations with many countries around the world, aimed at establishing and developing relations in various fields. Such a relationship is primarily reflected in the legal documents. Achieving their comprehensive development has been analyzed in many respects by comparing the linguistic features of the legal terminology of foreign languages with the Uzbek language [3, p. 3].

\section{ATERIAL AND METHODS}

One of the current issues of modern linguistics is a detailed description and classification of English and Uzbek phraseological units with legal meaning, which are an integral part of the field lexicon.

It is well known that phraseological unity (two fixed expressions) is a linguistic means that reflects the worldview. A person's attitude to a particular object is expressed through expressions, expresses the feelings of the perceiving person and expresses his attitude to the events taking place around him. It is well known that stable expressions are the unique wealth of every nation. Phrases are an important source of cultural heritage and values from generation to generation. 
Oriental Journal of History, Politics and Law Vol.1 (1), pp.01-03, 23 May, 2021 Available online at http://supportscience.uz/index.php/ojhpl (C) 2021 Support Science LLC

DOI: https://doi.org/10.37547/supsci-ojhpl-01-01

Their meaning reflects legends, national values, customs, traditions, lifestyle and other valuable national-cultural and enlightenment-religious information. It is also possible that the expressions are closely related to historical events and historical figures. Their content even reflected religious knowledge and religious concepts.

In linguistics, it is often seen as a phraseological unit relative to phrases. It is no coincidence that the national-cultural problems of the phraseological system have become the object of study of many linguists to this day. This can be explained by the attention and interest in the problem of "Language and Culture" in recent years, as well as the development of modern linguistics in the anthropological paradigm. Given the interdependence of language with man, the need to apply the theory of anthropological linguistics to the phraseological system, aimed at the study of his consciousness, worldview, spiritual and practical activities, is a natural and important reality [7, p. 1213].

E. Sepir's research focused on language and culture. "Language does not live in isolation from culture ... Language is an indicator of the culture of the people, because in its vocabulary the culture of the people it serves is clearly described" [5, p. 194].

As noted by M.I. Rasulova, "phraseological units reflect the psychology of the people and are a source for indepth study of the history and culture of the people" [4, p. 207].

Phraseology is an important source that reflects a specific socio-historical period of a particular nation. Extralinguistic factors also play an important role in this $[1$, p. 52].

Phraseological units are, to put it simply, different meanings formed in the structure of phrases. This article analyzes phrases with legal semantics or legal content. Such expressions help to define the legal knowledge and consciousness of the members of the society, the essence of the science of law and the legal rules in force in a particular society. We know that each national language system has its own legal terms and documents. Our article, based on the example of English and Uzbek, will undoubtedly provide a platform for future lawyers, judges, human rights defenders and business people to learn English effectively. According to I. Kh. Sodikova, it is necessary to create educational terminological dictionaries in independent Uzbekistan for the training of highly qualified lawyers, as well as for the development of national law in the country, taking into account the practice of international and foreign law, translation from foreign languages into various languages [6, p . 20]. Such dictionaries also include phraseological units that have legal meaning.

Expressions in the legal context reflect sensitive issues related to people's legal relationships. Moreover, this topic has not yet been studied in detail and comprehensively.

The English phrase Queens's counsel (jurid.) Queen's Advocatell [2, p.56] provides information about the monarchical structure of England. There is no Uzbek alternative to this phraseological unit. Because the socio-political governance of our country is based on democratic principles, not monarchy similarly, the longer liver (law) - The last of the survivors\|l [2, p. 63] cannot find its alternative or analogue in the phraseology of the Uzbek language, because it has a national character. Therefore, when translating it from one language to another, it is possible to convey its content to the listener only on the basis of lexical translation.

The semantics of some legal concepts are consistent in both languages. For example, in English the natural person [2, -p. 86] is applied to an individual. A legal entity is called an artificial person [2, -p. 86]. Similar legal terms are found in Uzbek: natural person and legal entity.

\section{ESULTS AND DISCUSSION}

It should be noted that the concepts of inheritance and heir are actively used in legal relations in all languages. They are also available in English and Uzbek. For example, the English phrase next to kin, which has a very important and interesting legal meaning [2, p. 82] - means the closest relative who inherits in the absence of a will. Even if such phraseology does not exist in the Uzbek language, we may encounter a state of inheritance. There is no separate language unit (phrase) in the phraseological reserve of the Uzbek language, which represents such an heir, but the following legal terms are actively used as possible alternatives: heir, sole heir, legal heir, testamentary will and others.

Another of the phraseological units in English contains the names of specific states. However, they represent a completely different meaning. For example: the Courtesy of England (Scotland) [2, p. 20]. It means a widow who inherits from his wife (must have children). Also, phraseological units containing anthroponyms in English make up the vast majority. This is due, firstly, to the fact that historical events are related to the 
Oriental Journal of History, Politics and Law Vol.1 (1), pp.01-03, 23 May, 2021 Available online at http://supportscience.uz/index.php/ojhpl (C) 2021 Support Science LLC

DOI: https://doi.org/10.37547/supsci-ojhpl-01-01

activities of celebrities in the social and political life of the country, and secondly, they are phraseologies that occur directly in the communicative process. For example: Jack Ketch - executioner (associated with the name of the famous executioner in the XVII century); Teddy Boy - elevator (associated with the name of King Edward VII of England, who has a unique style of dress); A smart Aleck is a confident, unassuming beta.

In the Uzbek language, anthroponymic phraseological units are mainly formed in the communicative process and do not have a significant share [7, p. 139]. Sometimes fixed English phrases with legal meanings refer to religious ceremonies and religious concepts for example, the devil's advocate. Literally translated, he is the "advocate" of Satan, but the phrase is used figuratively: "a person who pays attention only to the qualities and shortcomings of the faith of men." The emergence of this phrase is associated with the word of objection to the priest in the medieval Vatican in the ceremony of confirming a person as a saint on behalf of the church. The phraseology similar to the meaning and structure of the phrase the God's advocate was used in the middle Ages in the Vatican to refer to a priest who spoke and defended a person on behalf of the church as a saint. Of course, these expressions are still archaic today. However, from the point of view of jurisprudence, history and religion, they are very meaningful and play an important role in various communication situations.

\section{Conclusion}

In conclusion, the study of legal expressions is a very topical issue that provides a basis for determining people's knowledge of law and jurisprudence. Such a study, conducted on the example of English and Uzbek languages, allows us to observe the specifics of the legal and legal activities of language owners in society.

\section{References}

1. Mamatov A.E. Problems of formation of Uzbek phrases: Doctor of Philological Sciences. ... diss. avtoref.- Toshkent, 1999. -p. 56

2. Nasrullaeva N.Z. English-Russian-Uzbek dictionary of gender-marked phraseological units Toshkent: 2018. -p. 112

3. Nishonov P.P. Comparative-typological study of legal terminology of French and Uzbek languages, Candidate of Philological Sciences .... diss. avtoref. -Tashkent: 2009. -p. 26.

4. Rasulova M.I. Fundamentals of lexical categorization in linguistics, - Toshkent: Fan, 2005. -p. 268.

5. Sapir E. Selected works on linguistics and cultural studies. Moscow: 1993. -pp. 20-203

6. Sadykova I.Kh. The principles of compiling the "English-Russian-Uzbek educational dictionary of legal terms" Abstract of thesis. diss. .... Cand. philol. sciences. Tashkent: 1998. -p. 21

7. Ergasheva G.I. Comparative-typological study of the gender aspect in phraseology and paremia of English and Uzbek languages. Filol. candidate of sciences .... diss. Tashkent: UzMU, 2011. -p. 154. 